\title{
The Influence of Ethical Leadership, Intrinsic Motivation, and Work Commitments on Job Satisfaction (Study of the Ministry of Religion, Padang City and Pasaman District)
}

\author{
Trisno Trisno ${ }^{1}$, Abror Abror ${ }^{2 *}$ \\ ${ }^{1}$ Universitas Negeri Padang, Padang, Indonesia, $₫$ tisno.petualang@gmail.com \\ 2 Universitas Negeri Padang, Padang, Indonesia, $₫$ abror094@ gmail.com; abror094@fe.unp.ac.id \\ ${ }^{*}$ Corresponding Author
}

\begin{abstract}
The purpose of this study was to see the effect of ethical leadership, intrinsic motivation and work commitment on the job satisfaction of employees of the Ministry of Religion office in Padang City and employees of the Ministry of Religion office in Pasaman Regency. The sample in this study were 97 people. The type of data used is primary data obtained from questionnaires shared. Analysis methods using Partial Least Square (SEM PLS). The results of this study indicate (1) ethical leadership has a significant effect on intrinsic motivation, (2) ethical leadership has a significant effect on job satisfaction, (3) intrinsic motivation has a significant effect on job satisfaction, (4) ethical leadership has a significant effect on work commitment, (5) Intrinsic motivation has a significant effect on work commitment, (6) work commitment does not have a significant effect on job satisfaction.
\end{abstract}

Keywords: Ethical Leadership, Intrinsic Motivation, Work Commitment, Job Satisfaction.

\section{Introduction}

Employee satisfaction is one of the topics that is always interesting and important for both scientists and practitioners. Job satisfaction affects the organization activities as a whole. Every organization has a goal to achieve optimal performance. Improving organizational performance as optimal as possible is inseparable from employee job satisfaction, as one of the factors that determine organizational performance. Related to efforts to increase employee job satisfaction, one of the basic problems is how to actually improve employee job satisfaction.

The phenomenon that researchers have found is related to job satisfaction, which is based on the results of interviews with several employees of the Padang Ministry of Religion office and employees of the Pasaman District Ministry of Religion. For example, the administration of employees is very bored with the work assigned to them so that the task given to them is not done well. The head of the Ministry of Religion should provide more challenging tasks or jobs to his employees. In addition, there is a lack of explanation of the tasks given by the leadership to employees so that employees cannot do their jobs properly because they do not know what to do. Plus, the discipline of employees of the Ministry of Religion is still relatively low. This can be seen in the timing of work. Often there are delays in working hours, and others due to uncertainty over time.

Creating employee job satisfaction is not easy because job satisfaction can be created if the variables that influence it include ethical leadership style, work commitment and intrinsic motivation run well and in accordance with the wishes of all employees in an organization or company. Based on this background, the researcher raised the title "The Influence of Ethical Leadership, Intrinsic Motivation and Work Commitment on Job Satisfaction of Padang City Ministry of Religion Ministry Employees and Ministry of Religion Office Employees in Pasaman Regency".

The objectives of this study include :

1. Determine the influence of ethical leadership on the intrinsic motivation of employees of the Ministry of Religion Office in the City of Padang and Pasaman Regency

2. Determine the effect of ethical leadership on the job satisfaction of employees of the Ministry of Religion Office in the City of Padang and Pasaman Regency 
3. Determine the effect of the influence of intrinsic motivation on the job satisfaction of employees of the Ministry of Religion Office of the City of Padang and Pasaman Regency

4. Determine the influence of ethical leadership on the work commitment of employees of the Ministry of Religion of Padang City and Pasaman Regency

5. Determine the influence of intrinsic motivation on the work commitment of employees of the Ministry of Religion Office in the City of Padang and Pasaman Regency

6. Determine the effect of work commitment on job satisfaction of employees of the Ministry of Religion Office in the City of Padang and Pasaman Regency

\section{Theoretical Review}

\section{Job Satisfaction}

Job satisfaction is a measure of the rate at which employees are satisfied and happy with their work (Dawal et al., 2009). Ali et al. (2016) states that job satisfaction is an emotional answer to work and the social and physical situation of the work environment. Job satisfaction refers to the feeling of one's satisfaction at work, which acts as a motivation to work (Munir et al., 2016). Job satisfaction is higher when a person feels that he has control over a given task (Dawal et al., 2009). Job satisfaction refers to employees' attitudes or opinions about the work itself or the relevant environment and their overall emotional response to their work role and is one indicator of happiness (Ouyang et al., 2015).

Factors that influence job satisfaction can be influenced by motivation (Ali et al., 2016; Anghelache, 2015; Kars and Iskender, 2009; Saleem et al., 2010) ethical leadership (Yates, 2014), organizational culture (Brazil et al. ., 2010; Disiru, et al., 2018; MacIntosh and Doherty, 2010; Panagiotis et al., 2014). To measure employee job satisfaction, Saleem et al. (2010) measure employee job satisfaction with the following indicators: 1) I am often bored with my job 2) I feel quite satisfied with my current job 3) almost every day I am enthusiastic about work I 4) I find real pleasure in my work 5) I am satisfied with the award I get for work 6) I am satisfied with the promotion opportunity 7) I am satisfied with the amount of variation in my work.

\section{Ethical Leadership}

Brown et al (2005) define ethical leadership as a demonstration of normative behavior through personal action and interpersonal relationships, and promote that behavior to followers through twoway communication, reinforcement, and decision making. Ethical leadership is seen as a just and principled decision maker (Zehir and Erdogan, 2011). Ethical leadership is believed to direct and guide organizational members towards goals and objectives that benefit organizations, their members, other stakeholders, and the community (Erci et al, 2012). According to Zhu et al (2015) ethical leaders are leaders who are honest, trustworthy, approachable, caring, and fair in decision making. Ethical leaders function as ethical role models for their subordinates, build and communicate ethical standards to subordinates, and enforce these standards through appreciation and sanctions.

Indicators of Ethical Leadership according to elci et, al. (2012) are: 1) leaders discuss business ethics and values with employees 2 ) leaders assess success not only based on results but also based on process 3) leaders provide examples of how to do ethically correct work 4) leaders listen to what employees say 5) leaders make fair and balanced decisions 6) leaders highly consider the interests of employees 7) leaders can be trusted 8) leaders run their lives ethically 9) leaders discipline employees who violate ethical standards 10) leaders when making decisions, ask what is right to do.

\section{Intrinsic Motivation}

According to Chowdhury (2007) motivation is the evolution of supportive and moving behavior from directed goals. Whereas Hafenbrack and Vohs (2018) say motivation is about achieving a different future (often better) than the present. According to Azar and Shafighi (2013) motivation is an internal state and strength, which encourages individuals to take certain actions. Furthermore there are a number of motivational factors that increase employee presentation in an organization (Zameer et al., 2014). 1) salary 2) bonus 3) encouragement 4) self security 5) promotion. Intrinsic motivation is measured using the Kuvaas et, al. (2017) namely: 1) the work I do is my driving factor in work 2) work in my workplace is very pleasant 3 ) my work means 4 ) my job is very interesting 5) interesting 
work is a motivation for me 6) sometimes- sometimes I am inspired by work so, forget about the environment.

\section{Work Commitments}

Employee commitment is defined as the rate at which a worker identifies, shares goals and values with his company (Alfalla-Luque, et. Al. 2015). According to Brzezinskia and Bak (2015) committed employees are people who are willing to act on their own initiative, even at the expense of their own convenience and treat each change as an opportunity. Employees who have high commitment have a positive impact on the organization's business performance, including increased productivity and efficiency and better relationships with customers. Whereas according to Mrayyan and Al-Faouri (2008) stated employee commitment related to performance in work. Employees who are highly committed will remain in the organization because they like their work.

According to factor influences commitment can be influenced by one's motivation (Bajpai and Rajpot, 2018), ethical leadership (Yates, 2014). Work commitments will be measured using indicators from Ellinger, et al (2013): 1) I strive to improve service quality in my institution 2) I like to discuss the quality of service with colleagues 3) I get personal satisfaction in providing quality service to customers 4) providing high quality is the number one priority for my agency 5) I really care about the quality of service in my agency.

\section{Hypothesis Development}

Syafii et, al. (2015) show that leadership style has a significant effect on employee motivation. Khuong and Hoang (2015) show that leadership styles have a strong influence in maintaining and developing employee motivation. Research by Alghazo and Al-Anazi (2016) found that there was a strong relationship between leadership style and employee motivation where the correlation was positive with transformational and negative styles with transactional style. The research conducted by Mehta et al. (2003) showed that leadership style consisting of participatory leadership style, supportive leadership style, and directive leadership style had a significant positive impact on motivation.

H1. Ethical leadership has a significant effect on intrinsic motivation

Yates (2014) states that employees led by ethical leaders are more satisfied with their work than those who are not led by ethical leaders. Çelik et al. (2015) in his study found that ethical leadership had a positive effect on job satisfaction. Attar et, al. (2017) shows that ethical leadership behavior has a positive effect on the level of employee job satisfaction. Furthermore Kim and Brymer (2011) also found that ethical leadership had a positive effect on job satisfaction.

H2. Ethical leadership has a significant effect on job satisfaction

Raza et, al. (2015) found that intrinsic motivation was positively related to job satisfaction. Suttikun et, al. (2018) shows that employees will have increased motivation if they believe their hard work will produce the desired results. If the desired results are met, the motivation cycle continues and job satisfaction increases. Karsh and Iskender (2009) revealed that motivation levels affect job satisfaction, where high motivation leads to high job satisfaction, and low motivation leads to low job satisfaction. Furthermore Saleem et al. (2010) found that there was a positive relationship between motivation and job satisfaction.

H3. Intrinsic motivation has a significant effect on job satisfaction

Yates (2014) states that employees led by ethical leaders are more committed to the organization than those who are not led by ethical leaders. Sheraz et al. (2017) also found that ethical leadership was positively related to organizational commitment. Pertiwi et, al. (2018) found that ethical leadership has a positive direct influence on affective commitment. Çelik et al. (2015) found that ethical leadership had a positive effect on organizational commitment.

H4. Ethical leadership has a significant effect on organizational commitment

Danish et al. (2012) found that motivation was significantly related to employee commitment. Furthermore, Kerse (2016) states that motivation influences organizational commitment. Salleh et, al. (2017) show that work motivation has a positive relationship with organizational commitment. Al- 
Madi et al. (2017) in his research also found that motivation had a significant effect on organizational commitment.

H5. Intrinsic motivation has a significant effect on work commitment

Çelik et, al. (2015) found that commitment had a positive effect on job satisfaction. Gomes (2009) also found organizational commitment had a positive effect on job satisfaction. Kappagoda (2012) also states that organizational commitment has a positive effect on job satisfaction. Akhtar et, al. (2015) show that organizational commitment has a positive influence on job satisfaction.

H6. Work commitment has a significant effect on job satisfaction.

\section{Methods}

This research was conducted at the employees of the Ministry of Religion office in Padang City and Pasaman Regency. The scope of this study is aimed at analyzing the influence of exogenous variables namely ethical leadership (X1), intrinsic motivation $(\mathrm{X} 2)$, and work commitment as (X3) on endogenous variables, namely job satisfaction $(\mathrm{Y})$ of Padang City Ministry of Religion office staff and Ministry of Religion office employees Pasaman Regency.

Population is a generalization area consisting of: objects / subjects that have certain qualities and characteristics set by the researcher to be studied and then conclusions drawn. The sample in this study uses the entire population without having to draw the research sample as an observation unit called a saturated sample (census sample). Because the population in this study was not greater than 100 respondents, namely 97 people.

The data analysis technique in this study uses PLS SEM. PLS is one of the variant-based SEM statistical methods designed to complete multiple regression when specific data problems occur, such as small research sample sizes, missing values, and multicollinearity. PLS produces more robust parameters without changing the sample from the population. The use of PLS analysis tools in this study on the grounds that PLS requires a relatively small population, that is, a minimum recommended range of 30 to 100 respondents.

\section{Results and Discussion}

\section{Measurement Outer Model}

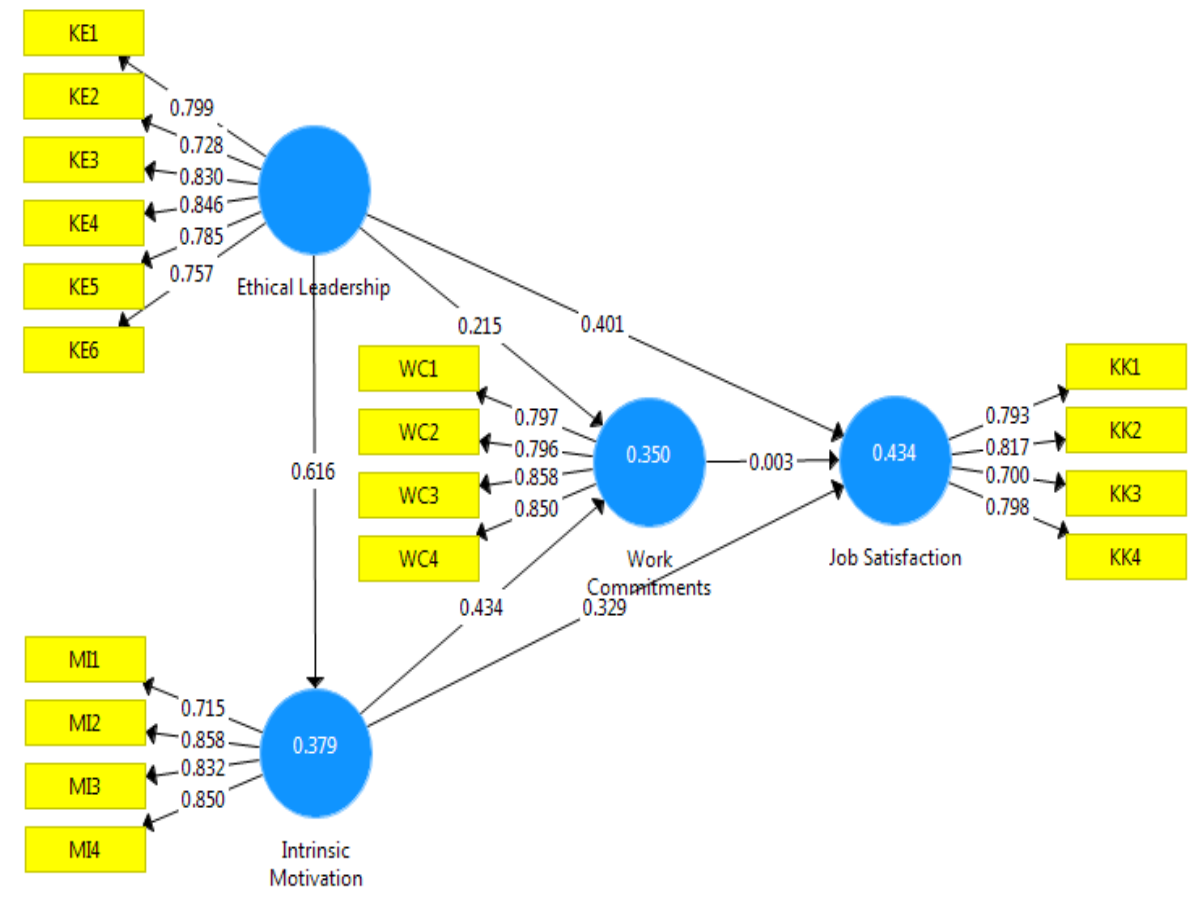

Figure 1

Display of Algorihman PLS Results 


\section{Measurement Inner Model}

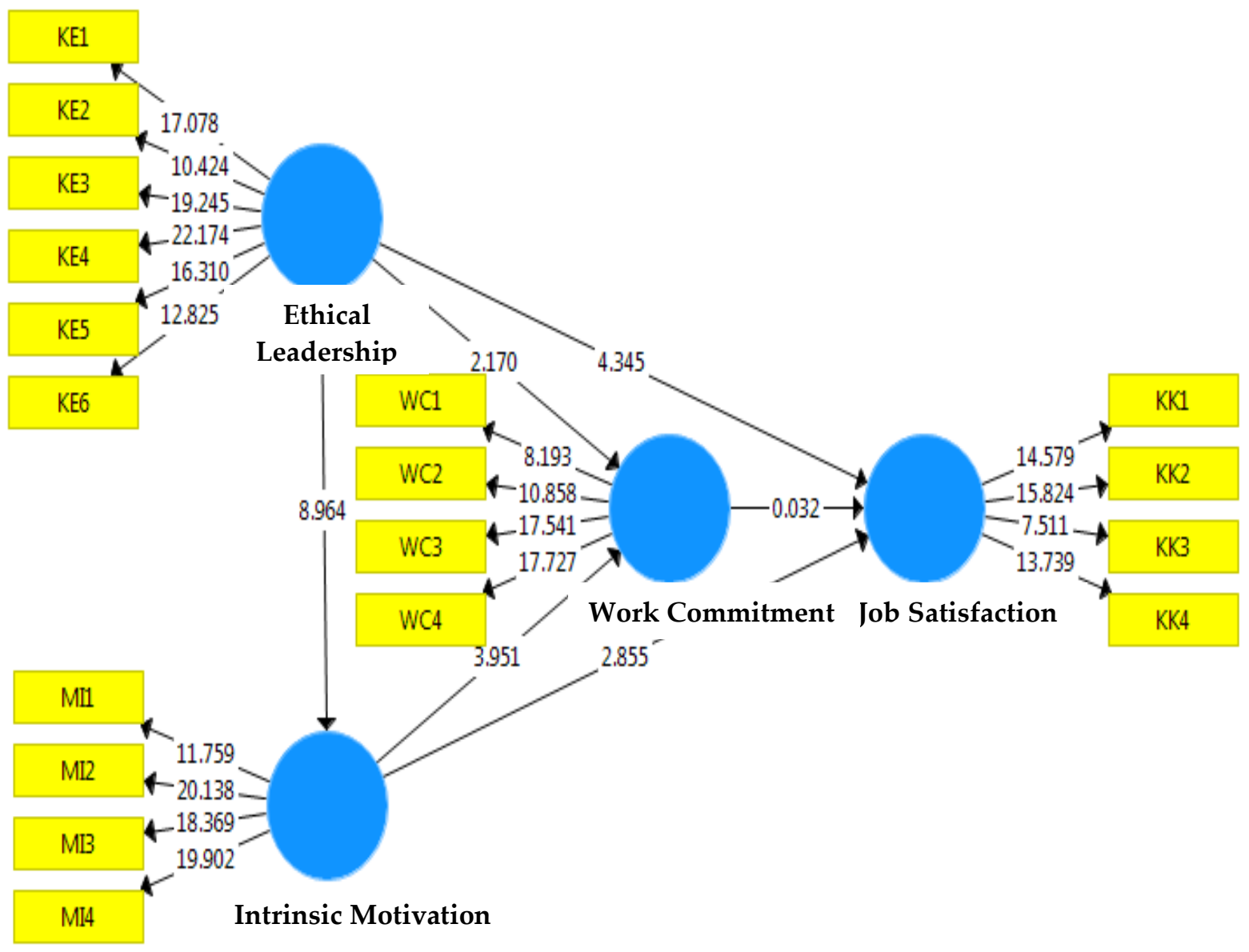

Figure 2

Display of PLS Bootstrapping Rusults

Table 1 Hypothesis testing

\begin{tabular}{lllllll}
\hline \multicolumn{1}{c}{ Hipotesis } & & & $\begin{array}{c}\text { Koefisiensi } \\
\text { Path }\end{array}$ & $\begin{array}{c}\text { t- } \\
\text { statistik }\end{array}$ & P-Values & Information \\
\hline H1 Ethical Leadership & $\rightarrow$ & Intrinsic Motivation & 0,616 & 8,964 & 0,000 & Accepted \\
\hline H2 Ethical Leadership & $\rightarrow$ & Job Satisfaction & 0,605 & 9,066 & 0,000 & Accepted \\
\hline H3 Intrinsic Motivation & $\rightarrow$ & Job Satisfaction & 0,331 & 3,349 & 0,001 & Accepted \\
\hline H4 Ethical Leadership & $\rightarrow$ & Work Commitments & 0,483 & 4,917 & 0,000 & Accepted \\
\hline H5 Intrinsic Motivation & $\rightarrow$ & Work Commitment & 0,434 & 3,951 & 0,000 & Accepted \\
\hline H6 Work Commitment & $\rightarrow$ & Job Satisfaction & 0,003 & 0,032 & 0,032 & Not \\
& & & & & & Accepted \\
\hline
\end{tabular}

Based on the results of the study it can be seen that ethical leadership significantly influences intrinsic motivation. This finding supports previous research, namely the Syafii et al. (2015) show that leadership style has a significant effect on employee motivation. Khuong and Hoang (2015) show that leadership styles have a strong influence in maintaining and developing employee motivation. Research by Alghazo and Al-Anazi (2016) found that there was a strong relationship between 
leadership style and employee motivation where the correlation was positive with transformational and negative styles with transactional style. The research conducted by Mehta et al. (2003) showed that leadership style consisting of participatory leadership style, supportive leadership style, and directive leadership style had a significant positive impact on motivation.

This finding supports previous research, namely Yates's (2014) study states that employees led by ethical leaders are more satisfied with their work than those who are not led by ethical leaders. Çelik et, al. (2015) in his study found that ethical leadership had a positive effect on job satisfaction. Attar et, al. (2017) shows that ethical leadership behavior has a positive effect on the level of employee job satisfaction. Kim and Brymer (2011) also found that ethical leadership had a positive effect on job satisfaction.

This finding supports previous studies, namely Raza et al. (2015) found that intrinsic motivation was positively related to job satisfaction. Suttikun et, al. (2018) shows that employees will have increased motivation if they believe their hard work will produce the desired results. If the desired results are met, the motivation cycle continues and job satisfaction increases. Karsh and Iskender (2009) revealed that motivation levels affect job satisfaction, where high motivation leads to high job satisfaction, and low motivation leads to low job satisfaction. Furthermore Saleem et al. (2010) found that there was a positive relationship between motivation and job satisfaction.

The results of this study supported by Yates (2014) state that employees led by ethical leaders are more committed to the organization than those who are not led by ethical leaders. Sheraz et al. (2017) also found that ethical leadership was positively related to organizational commitment. Pertiwi et, al. (2018) found that ethical leadership has a positive direct influence on affective commitment. Çelik et, al. (2015) found that ethical leadership had a positive effect on organizational commitment.

This finding supports previous research, namely Danish et al. (2012) found that motivation was significantly related to employee commitment. Furthermore, Kerse (2016) states that motivation influences organizational commitment. Salleh et al. (2017) show that work motivation has a positive relationship with organizational commitment. Al-Madi et al. (2017) in his research also found that motivation had a significant effect on organizational commitment. When a leader can understand the needs of employees and motivate employees then it increases employee work commitment.

Based on the results of the study it can be seen that work commitment does not have a significant effect on job satisfaction. The results of this study conflict with research Çelik et, al. (2015) found that commitment had a positive effect on job satisfaction. Gomes (2009) also found organizational commitment had a positive effect on job satisfaction. Kappagoda (2012) also states that organizational commitment has a positive effect on job satisfaction. Akhtar et, al. (2015) show that organizational commitment has a positive influence on job satisfaction.

\section{Conclusions}

1. Ethical leadership has a significant effect on the intrinsic motivation of employees of the Ministry of Religion of Padang City and Pasaman Regency, this shows the better the ethical leadership of someone in understanding the needs of employees, the higher intrinsic motivation of employees in obeying their leaders.

2. The influence of ethical leadership on job satisfaction is significant, this shows that the better the ability of a leader in understanding the needs of employees, the higher the job satisfaction of employees.

3. Intrinsic motivation has a significant effect on job satisfaction, this indicates a good ability of a leader to his subordinates so that it can affect the level of employee job satisfaction.

4. The influence of ethical leadership on work commitment is significant, this shows that the better ethical leadership will affect employee organizational commitment. The better ethical behavior in a leader, it will potentially increase the behavior of employee work commitment.

5. Intrinsic motivation has a significant effect on employee work commitment, this shows that when a leader can understand the needs of employees and motivate employees it will increase employee work commitment. 
6. The effect of work commitment on job satisfaction is not significant, this shows that the higher or lower the level of work commitment of employees, it will not affect the job satisfaction of employees of the Ministry of Religion office in Padang City and Pasaman Regency.

\section{References}

Akhtar, A., Durrani, A. B., dan Hassan, W., (2015). The Impact of Organizational Commitment on Job Satisfaction and Job Performance: An Empirical Study from Pakistan. IOSR Journal of Business and Management (IOS-JBM), 17 (6) II: 75 - 80.

Alfalla-Luque, R., Marin-Garcia, J.A., Medina-Lopez, C., (2015). An analysis of the direct and mediated effects of employee commitment and supply chain integration on organisational performance. International Journal of Production Economics

Alghazo, A. M., dan Al-Anazi, M., (2016). The Impact of Leadership Style on Employee's Motivation. International Journal of Economics and Business Administration, 2(5): 37-44.

Al-Madi, F. N., Assal, H., Shrafat, F., dan Zeglat, D., (2017). The Impact of Employee Motivation on Organizational Commitment. European Journal of Business and Management, 9 (15): 134 - 145.

Azar, M., dan Shafighi, A. A., (2013). The Effect of Work Motivation on Employees' Job Performance (Case Study: Employees of Isfahan Islamic Revolution Housing Foundation). International Journal of Academic Research in Business and Social Sciences. 3 (9): 432-445

Azanza, G., Moriano, J. A., dan Molero, F., (2013). Authentic leadership and organizational culture as drivers of employees' job satisfaction. Journal of Work and Organizational Psychology, 29, 45-50.

Brazil, K. et, al. (2010). Organizational Culture Predicts Job Satisfaction and Perceived Clinical Effectiveness in Pediatric Primary Care Practices. Journal Health Care Management Review: 365371, DOI: 10.1097/HMR.0b013e3181edd957

Brzezinskia, S. Dan Bak, A., (2015). Management of Employees' Commitment in the Process of Organization Transformation. Procedia Economics and Finance, 27: 109 - 115.

Çelik, S., Dedeoğlu, B. B., dan Inanir, A., (2015). Relationship Between Ethical Leadership, Organizational Commitment and Job Satisfaction at Hotel Organizations. Ege Academic Review, 15 (1): 53 - 63.

Cetin, M., Karabay, M. E., dan Efe, M. N., (2012). The Effects of Leadership Styles and the Communication Competency The Case of Turkish Banks, 8th International Strategic Management Conference. Procedia - Social and Behavioral Sciences, 58, 227 - 235.

Chowdhury, M., (2007). Enhancing Motivation and Work Performance of The Salespeople: The Impact of Supervisors' Behavior. African Journal of Business Management, 1(9): 238-243

Danish, R. Q., Saif-Ur-Rehman dan Munir, Y., (2012). The Impact of Motivation on Employee's Commitment: Evidence from Public and Private Sector of Pakistan. World Review of Business Research, 2 (1): 109 - 118.

Dawal, S. Z., Tahaa, Z., dan Ismail, Z., (2009). Effect of job organization on job satisfaction among shop floor employees in automotive industries in Malaysia. International Journal of Industrial Ergonomics, 39, 1-66.

Dirisu, J. et, al. (218). An Integrated Dataset on Organisational Culture, Job Satisfaction and Performance in The Hospitality Industry. Journal Department of Business Management, Covenant University, Nigeria. 19: 317-321

Elci. M., et, al. (201). The Impact of Ethical Leadership and Leadership Effectiveness on Employees' Turnover The Mediating Role of Work Related Stress. Journal: International Strategic Management Conference. Procedia - Social and Behavioral Sciences 58 ( 2012 ) $289-297$

Ellinger, A.E., Musgrove, C.C., F., Ellinger, A.D., Bachrach, D.G., Baş, A.B.E., dan Wang, Y.-L., (2013). Influences of organizational investments in social capital on service employee commitment and performance. Journal of Business Research, 66: 1124-1133.

Gomes, D.R., (2009). Organizational Change and Job Satisfaction: The Mediating Role of Organizational Commitment. Exedra: Revista Científica, (1):177-195. 
Hafenbrack, A. C., dan Vohs, K. D. (2018). Mindfulness Meditation Impairs Task Motivation but Not Performance. Organizational Behavior and Human Decision Processes, 147, 1-15, doi:10.1016/j.obhdp.2018.05.001

Jogianto. (2011). Concept and Application of Variant-Based Sructural Equation Modeling in Business Research. Yogyakarta: STIM YKPN

Kappagoda, S. (2012) “Organizational Commitment: A Mediator of the Relationship Between Job Satisfaction and Job Performance in the Commercial Banks in Sri Lanka" Academicia: An International Multidisciplinary Research Journal, 2 (9):1-11.

Karhs, M. D., dan Iskender, H., (2009). To examine the effect of the motivation provided by the administration on the job satisfaction of teachers and their institutional commitment, World Conference on Educational Sciences 2009. Procedia Social and Behavioral Sciences 1, 2252-2257.

Kerse, G., (2016). The effects of the motivational tools on the organizational commitment: comparison of the Generation $\mathrm{x}$ and $\mathrm{y}$ in public institutions. Business $\mathcal{E}$ Management Studies: An International Journal, 4 (1): 1-23.

Khuong, M. N dan Hoang, D. T., (2015). The Effects of Leadership Styles on Employee Motivation in Auditing Companies in Ho Chi Minh City, Vietnam. International Journal of Trade, Economics and Finance, Vol. 6, No. 4, August 2015 210-217, DOI: 10.7763/IJTEF.2015.V6.471

Kim, W. G., \& Brymer, R. A. (2011). The effects of ethical leadership on manager job satisfaction, commitment, behavioral outcomes, and firm performance. International Journal of Hospitality Management, 30(4), 1020-1026.

Kuvaas. B. et, al. Do Intrinsic and Extrinsic Motivation Relate Differently to Employee Outcomes. (2017). Journal of Economic Psychology 61 (2017) 244-258

Munir, R. I. S., Rahman, R. A., Malik, A. M. A., dan Ma'amor, H., (2012). Relationship between Transformational Leadership and Employees' Job Satisfaction among the Academic Staff, International Congress on Interdisciplinary Business and Social Science 2012 (ICIBSoS 2012). Procedia-Social and Behavioral Sciences, 65, 885-890.

Mehta, R., Dubinsky, A. J., dan Anderson, R. E., (2003) "Leadership style, motivation and performance in international marketing channels", European Journal of Marketing, 37(1/2): 50 85, http://dx.doi.org/10.1108/03090560310453939

Mrayyan, M. T. dan Al-faouri, I., (2008). Predictors Of Career Commitment And Job Performance Of Jordanian Nurses. Journal of Nursing Management, 16: 246-256.

Nielsen, K., Yarker, J., Randall, R., dan Munir, F., (2009). The mediating effects of team and selfefficacy on the relationship between transformational leadership, and job satisfaction and psychological well-being in healthcare professionals: A cross-sectional questionnaire survey. International Journal of Nursing Studies, 46, 1236-1244.

Quyang, Z., Sang, J., Li, P., Peng, J., (2015). Organizational justice and job insecurity as mediators of the effect of emotional intelligence on job satisfaction: A study from China. Personality and Individual Differences, 76, 147-152.

Pertiwi, R., Mukhtar, M., dan Supriyati, Y., (2018). The Influence Of Ethical Leadership, Integrity And Affective Commitment On Organizational Citizenship Behaviour Of Teacher Of State Senior High School At The City Of Depok. Journal of Education and Practice, 9 (10): 30 - 38.

Raza, M. Y., Akhtar, M. W., Husnain, M., dan Akhtar, M. S., (2015). The Impact of Intrinsic Motivation on Employee's Job Satisfaction. Management and Organizational Studies, 2 (3): $80-88$.

Salau, O., Oludayo, O., Falola, H., Olokundun, M., Ibidunni, S., dan Atolagbe, T., (2018). Integrated datasets on transformational leadership attributes and employee engagement: The moderating role of job satisfaction in the Fast Moving Consumer Goods (FMCG) industry. Data in Brief, 19, 2329-2335.

Saleem, H., (2015). The impact of leadership styles on job satisfaction and mediating role of perceived organizational politics, Global Conference on Business \& Social Science-2014, GCBSS-2014, Kuala Lumpur. Procedia - Social and Behavioral Sciences, 172, $563-569$. 
Saleem, R., Azeem Mahmood, A., dan Mahmood, A., (2010). Effect of Work Motivation on Job Satisfaction in Mobile Telecommunication Service Organizations of Pakistan. International Journal of Business and Management, 5 (11): 213-222.

Salleh, S. M., Zahari, A. S. M., Said, N. S. M., dan Ali., S. R. O., (2016). The Influence of Work Motivation on Organizational Commitment in the Workplace. Journal of Applied Environmental and Biological Sciences, 6(5S)139-143.

Sheraz, A., Afzal, M. M., dan Rehman, K., (2017). Testing a Model of Ethical Leadership, Organizational Commitment and Its Outcomes with Social Exchange as Mediating Variable: A Pakistani Corporate Sector Perspective. Journal of Managerial Sciences, XI (03): 343 - 370.

Suttikun, C., Chang, H. J., dan Bicksler, H., (2018). A qualitative exploration of day spa therapists' work motivation and job satisfaction. Journal of Hospitality and Tourism Management, 34, 1-10.

Syafii, L. I., Thoyib, A., Nimran, U., dan Djumahir. (2015). The Role of Corporate Culture and Employee Motivation as a Mediating Variable of Leadreship Style related with the Employee Performance (Studies in Perum Perhutani), 2nd Global Conference on Business and Social Science-2015, GCBSS-2015, Bali, Indonesia. Procedia - Social and Behavioral Sciences, 211, 1142 1147

Yates, L. A., (2014). Exploring the Relationship of Ethical Leadership with Job Satisfaction, Organizational Commitment, and Organizational Citizenship Behavior. The Journal of ValuesBased Leadership, 7 (1) Winter/Spring.

Zameer, H., Ali, S., Nisar, W., dan Amir. M., (2014). The Impact of the Motivation on the Employee's Performance in Beverage Industry of Pakistan. International Journal of Academic Research in Accounting, Finance and Management Sciences, 4 (1): 293-298, doi: 10.6007/IJARAFMS/v4-i1/630

Zareie, B. dan Navimipour, N. J., (2016). The Effect Of Electronic Learning Systems On The Employee's Commitment. The International Journal of Management Education, 14: 167-175.

Zehir, C., dan Erdogan, E., (2011). The Association between Organizational Silence and Ethical Leadership through Employee Performance, 7th International Strategic Management Conference. Procedia Social and Behavioral Sciences, 24: 1389-1404.

Zhu, W., He, H., Treviño, L. K., Chao, M. M., dan Wang, W., (2015). Ethical leadership and follower voice and performance: The role of follower identifications and entity morality beliefs. The Leadership Quarterly xxx (2015) xxx-xxx 